\title{
Sosialisasi Dampak Pernikahan Dini
}

\author{
Eko Yuli Astuti ${ }^{*}$, Novita Setyoningrum² \\ ${ }^{1,2} \mathrm{Ilmu}$ Hukum, Universitas Islam Balitar, Jl. Majapahit No.2- 4, Kota Blitar, Indonesia, 66137 \\ Correspondence: ekoyuliastuti@unisbablitar.ac.id \\ Received: 30 Juni 2021 - Revised: 01 Agustus 2021 - Accepted: 16 Agustus 2021
}

\begin{abstract}
Abstrak. Pernikahan dini merupakan fenomena social yang banyak terjadi di berbagai wilayah. Faktor yang menjadi penyebab terjadinya pernikahan usia dini ialah pergaulan yang terlewat bebas yang berdampak pada maraknya perilaku seks bebas di kalangan remaja. Dilakukannya kegiatan ini bertujuan untu meningkatkan wawasan dan pengetahuan para santri agar tidak mudah melakukan seks bebas atau dengan mudah melakukan tindakan pernikahan dini yang disebabkan berbagai factor. Sehingga kejadian pernikahan dini dapat dicegah sedini mungkin. Pelaksanaan kegiatan pengabdian kepada masyarakat melalui pemberian sosialisasi mengenai dampak pernikahan dini berjalan dengan lancar. Peserta dinilai antusias dengan adanya kegiatan ini dan berharap kedepannya kegiatan seperti ini diadakan kembali.
\end{abstract}

Kata kunci: Dampak, pernikahan dini, santri, pondok pesantren

Citation Format: Astuti, E.Y. \& Setyoningrum, N. (2021). Sosialisasi Dampak Pernikahan Dini. Prosiding Seminar Nasional Abdimas Ma Chung (SENAM), 112-119. 


\section{PENDAHULUAN}

Perkawinan merupakan suatu peristiwa yang sakral. Perkawinan merubah status seseorang dari bujangan atau janda/duda menjadi berstatus kawin. Dari ikatan perkawinan yang ada diharapkan tercipta generasi baru yang lebih baik dari generasi sebelumnya (Djamilah, \& Kartikawati, 2014). Karena itu diperlukan persiapan yang cukup matang bagi pasangan yang akan memasukinya, baik berupa persiapan fisik dan mental ataupun persiapan lain yang bersifat sosial ekonomi. Usia perkawinan dini menjadi perhatian penentu kebijakan serta perencana program karena berisiko tinggi terhadap kegagalan perkawinan, kehamilan usia muda yang beresiko kematian maternal, serta risiko tidak siap mental untuk membina perkawinan dan menjadi orang tua yang bertanggung jawab. Ratarata usia kawin pertama yang rendah dari penduduk suatu daerah mencerminkan keadaan sosial ekonomi yang rendah pada daerah tersebut. Kemudian perempuan dan laki-laki tidak banyak mempunyai alternatif kegiatan lain sehingga menikah muda dan meninggalkan bangku sekolah (Suhadi, Bandowi \& Wulandari, 2018).

Pernikahan usia dini banyak terjadi utamanya di masyarakat pedesaan. Pernikahan anak usia dini sebenarnya tidak diperkenankan menurut Undang-Undang Perkawinan. Pada Pasal 7 ayat 1 UU Perkawinan menyebutkan bahwa perkawinan hanya diijinkan jika pihak pria sudah mencapai umur 19 tahun dan pihak wanita sudah mencapai usia 16 tahun. Berkaitan dengan hokum perkawinan yang berlaku di Indonesia, menurut Undang-Undang Nomor 1 Tahun 1974 tentang Perkawinan dijelaskan bahwa perkawinan adalah ikatan lahir batin antara seorang pria dan seorang wanita sebagai suami istri dengan tujuan membentuk keluarga (rumah tangga) yang bahagia dan kekal berdasarkan Ketentuan Yang Maha Esa. Sedangkan menurut Kompilasi Hukum Islam (KHI) merumuskan bahwa perkawinan menurut hokum Islam adalah pernikahan yaitu akad yang sangat kuat untuk menaati perintah Allah dan melaksanakannya merupakan ibadah.

Menurut Majelis Ulama Indonesia (MUI) dalam literature fikih Islam tidak terdapat ketentuan secara eksplisit mengenai batasan usia pernikahan. Baik itu batasan minimal maupun maksimal. Allah SWT. berfirman dalam surah An-Nur [24] : 32 yaitu "Dan kawinkanlah orang-orang yang sendirian di antara kamu dan orang-orang yang layak dari hamba-hamba sahayamu yang lelaki dan yang perempuan". Menurut sebagian ulama, yang dimaksud dengan layak adalah kemampuan biologis atau kemampuan untuk menghasilkan 
keturunan (Usman, 2017). Meski demikian, hikmah disyariatkannya pernikahan adalah menciptakan keluarga yang sakinah serta dalam rangka memperoleh keturunan.

Tingginya tingkat pernikahan dini di Blitar, rata-rata menikah di usia muda atau kisaran usia 14-15 tahun. Rata-rata usia kawin pertama yang rendah dari penduduk mencerminkan keadaan sosial ekonomi yang rendah di Blitar. Pernikahan dini rentan terhadap kekerasan dalam rumah tangga (KDRT), dengan perempuan sebagai korbannya dan biasanya berlangsung tanpa kesiapan mental dari pasangan berakhir dengan perceraian (Suhadi, Baidhowi, \& Wulandari, 2018). Ada pula dampaknya pada kesehatan perempuan. Karena dilakukan pada usia muda, seringkali organ reproduksi perempuan belum siap, sehingga bisa menyebabkan kesakitan, trauma seks berkelanjutan, pendarahan, keguguran, bahkan sampai yang fatal, kematian ibu saat melahirkan. Anak yang dilahirkan dalam pernikahan dini juga akan kena dampaknya, akta kelahiran sebagai salah satu hak anaka akan sulit didapatkan karena pernikahan yang dilakukan oleh orang tua yang belum cukup umur, yang KTP pun terkadang belum memiliki.

Faktor yang menjadi penyebab terjadinya pernikahan usia dini ialah pergaulan yang terlewat bebas yang berdampak pada maraknya perilaku seks bebas di kalangan remaja. Perilaku ini terjadi karena pengaruh film, lingkungan pertemanan, pesatnya informasi tanpa batas dari media social (Nur, 2019). Penyebab lainnya berupa lemahnya pengetahuan seks sejak dini, kurangnya pemahaman agama serta contoh dari orang tua yang juga melakukan pernikahan dini. Pernikahan dini merupakan permasalahan serius yang harus segera diberikan solusi, dan salah satunya adalah masyarakat harus paham dampak negatif dari pernikahan dini. Pasal 26 UU Nomor 23 Tahun 2002 tentang Perlindungan Anak, orang tua diwajibkan melindungi anak dari perkawinan dini, tetapi pasal ini, sebagaimana UU Perkawinan, tanpa ketentuan sanksi pidana sehingga ketentuan tersebut nyaris tak ada artinya dalam melindungi anak-anak dari ancaman perkawinan dini.

\section{MASALAH}

Pernikahan dini merupakan fenomena social yang banyak terjadi di berbagai wilayah. Fenomena pernikahan dini bagai fenomena gunung es yang hanya tampak sebagian kecil di permukaan, sangat sedikit terekspos di ranah publik, tetapi kenyataannya begitu banyak terjadi di kalangan masyarakat luas (Rifiani, 2011). Ketika ditelusuri, akar sejarah tentang pernikahan dini di Indonesia khususnya di pulau Jawa sebenarnya sudah 
menjadi sesuatu yang lumrah dilakukan oleh kakek nenek moyang kita. Pada konteks mereka, terdapat stigma negative jika seorang perempuan menikah di usia matang dalam komunitas mereka.

Simanjuntak, \& Doloksaribu, (2020) dalam penelitiannya menjelaskan bahwa isu pernikahan dini adalah salah satu topik yang menjadi perhatian penting pada kerangka kerjasama Sustainable Development Goals. Pemerintah di seluruh dunia sudah bersepakat menghapus perkawinan anak pada 2030. Pada riset United Nations Children's Fund (UNICEF) mencatat, satu dari enam anak perempuan di Indonesia menikah sebelum usia 18 tahun. Angkanya 340.000 anak per tahun. Adapun yang di bawah usia 15 tahun mencapai 50.000 anak per tahun. Maka tak heran apabila United National Development Economic and Social Affair (UNDESA), menempatkan Indonesia pada peringkat ke-37 dunia dan peringkat ke2 se-ASEAN sebagai salah satu negara dengan angka pernikahan usia dini yang tinggi. Oleh karena itu, masalah pernikahan dini haruslah segera diatasi.

\section{METODE PELAKSANAAN}

Kegiatan pengabdian ini dilakukan di Pondok Pesantren Tarbiyatus Sholihin. Metode pelaksanaan kegiatan dalam pengabdian kepada masyarakat ini meliputi langkahlangkah yaitu, 1) Penyampaian materi, dalam tahapan ini anggota pengabdian menyampaikan materi mengenai upaya penanggulangan paham radikalisme. 2) Tahapan diskusi. 3) Evaluasi

\section{HASIL DAN PEMBAHASAN}

Kegiatan pengabdian kepada masyarakat melalui sosialisasi dampak pernikahan dini dilakukan di Pondok Pesantren Tarbiyatus Sholihin pada hari Minggu, 20 Juni 2021 jam 10.00-11.00 WIB. Peserta dalam kegiatan ini berjumlah 20 orang yang terdiri dari santri Pondok Pesantren Tarbiyatus Sholihin. Kegiatan ini dilakukan dengan tujuan untuk meningkatkan pemahaman para santri mengenai dampak dari dilakukannya pernikahan dini. 


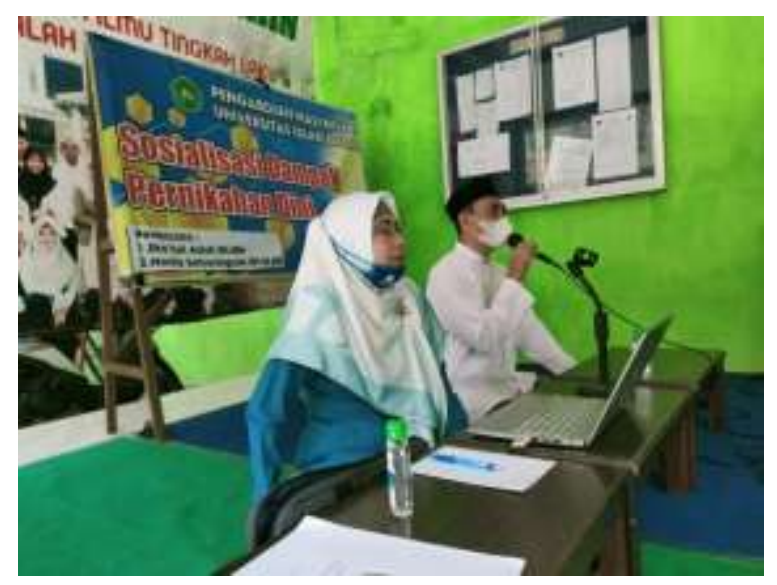

Gambar 1. Pembukaan oleh anggota pengabdian kepada masyarakat

Kegiatan pengabdian kepada masyarakat ini dimulai dengan sesi pertanyaan yang dilontarkan oleh narasumber tim pengabdian mengenai pemahaman peserta mengenai pernikahan dini. Sebagian peserta ada yang paham namun banyak juga yang belum mengerti. Kebanyakan dari mereka mengartikan bahwa pernikahan dini adalah sebagai bentuk pernikahan dibawah usia produktif dimana laki-laki berusia 25 tahun dan perempuan berusia 20 tahun.

Mendengar jawaban dari peserta kemudian narasumber anggota pengabdian menjelaskan mengenai Undang-Undang terkait pernikahan dini dan Hak Asasi Anak. Undang-Undang Nomor 1 tahun 1974 menjelaskan bahwa perkawinan hanya diijinkan jika pihak pria sudah mencapai umur 19 tahun dan pihak wanita sudah mencapai usia 16 tahun. Sedangkan pada Pasal 6 ayat 2 dijelaskan bahwa untuk melangsungkan pernikahan seorang yang belum mencapai umur 21 tahun harus mendapat ijin dari kedua orang tuanya. Kemudian disampaikan pula satu kasus mengenai pernikahan dini yaitu beberapa waktu yang lalu banyak disaksikan di berbagai media tentang seseorang yang sekaligus pengasuh pesantren yang bernama Syekh Puji yang berusia 43 tahun menikahi gadis belia yang berumur 12 tahun. Sehingga berita ini menarik perhatian khalayak karena dianggap peristiwa yang tidak lazim di masa sekarang ini.

Setelah penyampaian kasus tersebut narasumber menjelaskan mengenai dampak dilakukannya pernikahan dini. Dampak terhadap hokum pernikahan dini apabila dilakukan berarti telah mengabaikan beberapa hokum yang telah ditetapkan, atara lain : 
1. Undang-Undang Nomor 1 tahun 1974 tentang Perkawinan

2. Undang-Undang Nomor 23 Tahun 2002 tentang Perlindugan Anak. Pada Pasal 26 ayat 1 dijelaskan bahwa pernikahan dini dalam perspektif agama dan negara untuk mengasuh, mendidik, dan melindungi anak.

3. Undang-Undang Nomor 21 tahun 2007 tentang Pemberantasan Tindak Pidana Perdagangan Orang.

Selain dampak terhadap hukum, disampaikan pula dampak lain mengenai pernikahan dini yaitu :

a. Dampak biologis dan psikologis. Secara biologis organ-organ reproduksi anak yang baru menginjak akil baligh masih berada pada proses menuju kematangan sehingga belum siap untuk melakukan hubungan seks dengan lawan jenisnya, apalagi jika sampai hamil dan melahirkan.

b. Secara psikis anak belumsiap dan belum mengerti mengenai hubungan seks, sehingga akan menimbulkan trauma psikis berkepanjangan dalam jiwa anak yang nantinya sulit disembuhkan.

c. Dampak social dan perilaku seksual. Fenomena ini berkaitan dengan factor social budaya dalam masyarakat yang cenderung memposisikan wanita sebagai pelengkap kehidupan laki-laki saja.

Narasumber pengabdian kepada masyarakat di Ponpes Tarbiyatus Sholihin juga menjelaskan bahwa terdapat lima hak anak yang diabaikan dengan adanya pernikahan dini terutama bagi perempuan, yaitu sebagai berikut :

1. Hak untuk mendapatkan pendidikan, dengan kasus pernikahan dini anak tidak melanjutkan seklah sehingga tidak berkesempatan mengenyam pendidikan yang lebih tinggi. Tercatat hanya 5,6\% anak yang menikah di usia dini yang masih melanjutkan sekolah setelah menikah.

2. Hak untuk berpikir dan berekspresi. Banyaknya kasus pernikahan dini anak tidak lagi bisa berpikir dan berekspresi secara bebas sesuai dengan usianya karena dituntut dengan berbagai kewajiban sebagai seorang istri.

3. Hak untuk menyatakan pendapat dan didengar pendapatnya. Pada kenyataannya orang dewasa memandang bahwa anak belum mampu menentukan keputusan penting bagi 
dirinya sendiri. Oleh karena itu orang tuanyalah yang menentukan dan mengambil keputusan dengan mengatasnamakan kepentingan yang terbaik bagi anaknya.

4. Hak beristirahat dan memanfaatkan waktu luang, bergaul dengan teman sebaya, bermain, dan berekreasi.

5. Hak perlindungan, anak seharusnya dilindungi dari pernikahan dini baik mental, dan psikisnya.
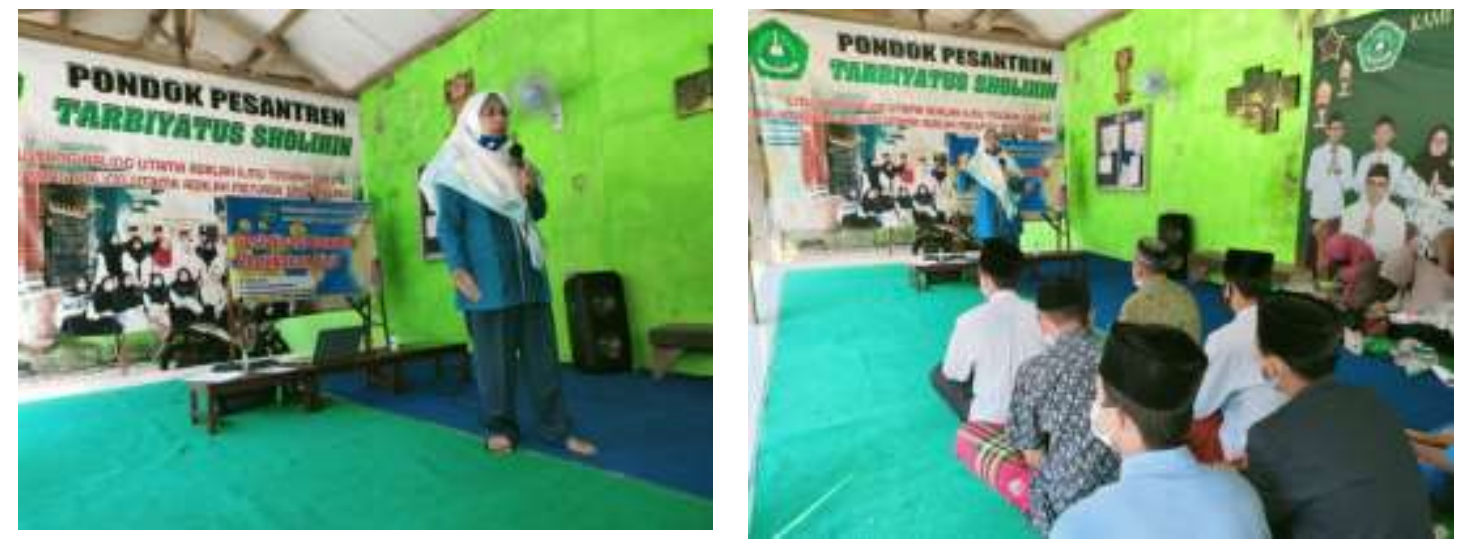

Gambar 2. Penyampaian materi

Setelah penyampaian materi selesai kemudian dilanjutkan dengan sesi tanya jawab. Dalam sesi ini peserta menanyakan mengenai materi yang kurang jelas sehingga narasumber mencoba menjelaskannya kembali dengan materi yang mungkin lebih bisa dipahami oleh para santri. Pelaksanaan kegiatan pengabdian kepada masyarakat melalui pemberian sosialisasi mengenai dampak pernikahan dini berjalan dengan lancar. Peserta dinilai antusias dengan adanya kegiatan ini dan berharap kedepannya kegiatan seperti ini diadakan kembali. Karena para santri sendiri menyadari bahwa fenomena pernikahan dini banyak terjadi di lingkungan Pondok Pesantren. sehingga dengan diadakannya kegiatan ini wawasan peserta mengenai pernikahan dini lebih luas sehingga dapat mencegah terjadinya pernikahan dini.

\section{KESIMPULAN}

Kegiatan pengabdian kepada masyarakat melalui pemberian sosialisasi mengenai dampak pernikahan dini di Podok Pesantren Tarbiyatus Sholihin berjalan dengan lancar. Dilakukannya kegiatan ini bertujuan untu meningkatkan wawasan dan pengetahuan para santri agar tidak mudah melakukan seks bebas atau dengan mudah melakukan tindakan pernikahan dini yang disebabkan berbagai factor. Sehingga kejadian pernikahan dini dapat dicegah sedini mungkin. 


\section{UCAPAN TERIMA KASIH}

Ucapan terimakasih kami sampaikan kepada keseluruhan anggota yang turut ikut membantu kegiatan pengabdian ini. Tak lupa kami sampaikan terimakasih kepada Universitas islam balitar yang telah mendanai kegiatan ini.

\section{DAFTAR PUSTAKA}

Djamilah, D., \& Kartikawati, R. (2014). Dampak perkawinan anak di Indonesia. Jurnal Studi Pemuda, 3(1), 1-16.

Nur, A. H. (2019). Peranan Tokoh Masyarakat dalam Upaya Pencegahan Kawin Muda di Desa Kateguhan Kecamatan Sawit Kabupaten Boyolali (Doctoral dissertation, Universitas Widya Dharma).

Rifiani, D. (2011). Pernikahan dini dalam perspektif hukum islam. Journal de Jure, 3(2).

Simanjuntak, S. M., \& Doloksaribu, M. (2020). Pengetahuan Siswa Tentang Resiko Menikah Dini Melalui Pendekatan Promosi Kesehatan. ABDIMAS: Jurnal Pengabdian Masyarakat, 3(2), 247-254.

Suhadi, S., Baidhowi, B., \& Wulandari, C. (2018). Pencegahan Meningkatnya Angka Pernikahan Dini dengan Inisiasi Pembentukan Kadarkum di Dusun Cemanggal Desa Munding Kecamatan Bergas. Jurnal Pengabdian Hukum Indonesia, 1(01), 31-40.

Undang-Undang Nomor 1 Tahun 1974 tentang Perkawinan

Undang-Undang Nomor 21 tahun 2007 tentang Pemberantasan Tindak Pidana Perdagangan Orang

Undang-Undang Nomor 23 Tahun 2002 tentang Perlindugan Anak

Usman, R. (2017). Makna pencatatan perkawinan dalam peraturan perundang-undangan perkawinan di Indonesia.

\section{(c) (1)}

(C) 2021 by authors. Content on this article is licensed under a Creative Commons Attribution 4.0 International license. (http://creativecommons.org/licenses/by/4.0/). 